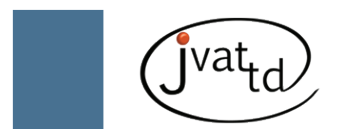

\title{
Cardiac evaluation after experimental intoxication by Amorimia rigida (Malpighiaceae) extracts in rabbits
}

Borboleta LR (1), Silva EF (1), Oliveira MS (1), Michel AFRM (2), Ferraz VP (3), Leite RC (1), Melo MM (1)

(1) School of Veterinary Medicine, Federal University of Minas Gerais (UFMG), Belo Horizonte, Minas Gerais State, Brazil; (2) Department of Veterinary Medicine, State University of Santa Cruz, Ilhéus, Bahia State, Brazil; (3) Department of Chemistry, Institute of Exact Sciences, Federal University of Minas Gerais (UFMG), Belo Horizonte, Minas Gerais State, Brazil.

\begin{abstract}
Clinical and laboratory changes were evaluated in rabbits after intoxication by Amorimia rigida, a plant that causes sudden death. Nine New Zealand male rabbits, averaging $3.54 \mathrm{~kg}$, were categorized into three groups $(n=3)$ and received, for eight consecutive days, the equivalent of $30 \mathrm{~g} / \mathrm{kg}$ dry matter of A. rigida water-soluble $(\mathrm{SG})$ and water-insoluble (IG) extracts via nasoesophageal route. The control group received water. There were no alterations in creatine kinase enzyme (CK), CK myocardial fraction (CKMB) or troponine I (cTnl). None of the animals had clinical or electrocardiographic (conventional and Holter) alterations. There were progressive decreases in the left ventricular ejection fraction and systolic fractional shortening. Doppler echocardiography alterations suggested a systolic dysfunction in the SG and IG groups and diastolic dysfunction in IG group. It was concluded that the soluble and insoluble extracts of $A$. rigida cause deficit of cardiac function.
\end{abstract}

Key words: toxic plant, Amorimia rigida, cardiac muscle profile, electrocardiography, echocardiography, rabbit.

\section{INTRODUCTION}

The genus Amorimia (Malpighiaceae) contains one of the 10 most important toxic plants in South America (1), best known of which is Amorimia rigida (Mascagnia rigida), well distributed in Minas Gerais state (Brazil), mainly in the northern and northeastern regions, where it is popularly known as "salsa-rosa" or "suma-roxa". It belongs to a group that causes acute intoxication that may provoke death preceded or not by a short period of clinical signs (2).

After A. rigida intake, animals may show apathy, anorexia, rigid walking, prolonged recumbence, muscle tremors and death, among other clinical signs. Significant alterations have not been found at necropsy of animals intoxicated by $A$. rigida. Multifocal infiltrate of lymphocytes in the myocardium associated with edema and congestion of myocytes was found in the histological exams (3).

Studies are necessary to elucidate which physiopathological mechanisms are involved in $A$. rigida intoxication that leads to sudden death. In spite of the existence of some reports of mortality in the absence of cardiac lesions, it is suggested that the main action of this plant in the heart may be due to its phytochemical characteristics that might affect cardiac function within a period insufficient to produce alterations detectable by optical microscopy (4).

To the best of our knowledge, no previous study has concurrently evaluated continuous electrocardiography (Holter), Doppler echocardiography and the cardiac muscle biochemical profile in animals after the intake of $A$. rigida. Thus, the present work aimed to ascertain the influence of this plant on the cardiac 
system using the rabbit as the experimental model.

\section{MATERIALS AND METHODS}

\section{Animal Assays}

Nine six-month-old white New Zealand male rabbits weighing an average of $3.54 \mathrm{~kg}$ were used. Firstly, they were dewormed with $1 \%$ ivermectin (Mectimax, Agener União Saúde Animal, Brazil) and housed in 90x90x40 cm individual metal pens, following a quarantine period. They were given water and commercial food (Nature Multivita, Socil Evialsis) ad libitum. The experiment was approved by the Ethics Committee on Animal Experimentation (CETEA), Federal University of Minas Gerais, protocol number 187/08.

\section{Preparation of Amorimia rigida Extracts}

The $12 \mathrm{~kg}$ of Amorimia rigida mature leaves utilized was collected from the rows of toxic plants located at School of Veterinary Medicine, Federal University of Minas Gerais (UFMG), Belo Horizonte, MG, Brazil. There is a voucher specimen of the plant deposited in the Herbário de Botânica based at the Institute of Biological Sciences at UFMG, maintained under the number 100819.

The extracts were crushed in a blender with ultra-pure water and sifted to obtain an aqueous solution, which was kept at $4^{\circ} \mathrm{C}$ for 24 hours in order to form two distinct phases. They were then separated into two solutions: soluble and insoluble in water, both being concentrated in a rotary evaporator vacuum system at $70^{\circ} \mathrm{C}, 80 \mathrm{rpm}$ (Dia Pump Aspirated Compressor, CA model).

To calculate the dry matter (DM) equivalent and sample concentration, five $A$. rigida leaves were sampled, weighed and placed into the incubator for 30 minutes, in quintuplicate. After drying, they were weighed and the mean DM value of $35 \%$ was obtained. The final concentrations of the solutions were $4.42 \mathrm{~g} / \mathrm{mL}$ of soluble extract and $2.71 \mathrm{~g} / \mathrm{mL}$ of insoluble extract, $\mathrm{pH} 5.54$.

The extracts were kept at $-20^{\circ} \mathrm{C}$. They were maintained at $4^{\circ} \mathrm{C}$ for $3 \mathrm{~h}$ and homogenized in an ultrasound bath (Branson 1510, Bransonic Ultrasonic Cleaner, USA) for 10 minutes before being administered to the animals.

\section{Experimental Groups}

Rabbits were equally distributed into three groups: $30 \mathrm{~mL}$ of water - control group (CG); 26 $\mathrm{mL}$ of $A$. rigida extract, soluble in water, equivalent to $30 \mathrm{~g} / \mathrm{kg}$ of plant DM - soluble group (SG); and $26 \mathrm{~mL}$ of $A$. rigida extract, insoluble in water, equivalent to $30 \mathrm{~g} / \mathrm{kg}$ of plant DM - insoluble group (IG). All extracts were administered twice daily, via nasoesophageal probe (\#6 urethral probe - Markmed): (8:30 am and 2:30 pm) for eight consecutive days.

\section{Image Diagnosing Techniques (Cardiovascular Examinations) and Cardiac Muscle Biochemical Profile}

Animals were clinically evaluated by electrocardiography (ECG) (electrocardiograph ECGPCVVET - Tecnologia Eletrônica Brasileira S.A.); continuous electrocardiography (Holter) (Cardiolight - Cardio's); echocardiography (HP Sonos 100 CF echocardiograph - Hewlett Packard); as well as by the following serum biochemical exams: aspartate aminotransferase (AST) (Synermed); lactate-dehydrogenase (LDH); creatine kinase (CK) (Bioclin CK - NAC and CK-MB - Quibasa Química Básica, Brazil); MB CK fraction (CK-MB); and troponin I (cTnI) (Troponin I Test Bioeasy - Belo Horizonte, Brazil), before ( $\mathrm{T} 0$ ) and after the administration of the extracts (day 3: T1, day 5: T2, day 7: T3, and day 9: T4).

ECG was performed at T0, T1, T3, and echocardiography and Holter at T0 and T4. Only one animal of each group was submitted to Holter examination. Previously rabbits had been sedated with $1 \mathrm{mg} / \mathrm{kg}$ midazolam maleate (Dormire, Cristália Produtos Químicos Farmacêuticos, Brazil) to minimize the stress and allow the examinations (5). Animals were shaved and electrodes for ECG were placed according to Tilley (6). Recordings were made in DI, at $50 \mathrm{~mm} / \mathrm{sec}$, and $2 \mathrm{~N} \mathrm{(7).} \mathrm{The} \mathrm{QT}$ interval was corrected using Carlsson formula (8). Electrodes for the Holter examination were placed on the thorax according to Oliveira et al. (9) being attached with bandages. Animals were using a cervical collar (10) and specific vest with a pocket where the Holter device was placed. Tracings were recorded throughout 14 hours. Echocardiography comprised bidimensional, M-mode, pulsed Doppler and color flow mapping evaluation methods as described by Stypmann et al. (11), considering the mean value of three measurements of each variable (12). 


\section{Statistical Analysis}

The experiment was carried out in a random sample / sampling design, arranged in subdivided parcels, with the groups being used as parcels and times as sub-parcels. The results were submitted to analysis of variance (ANOVA) and means were compared by Duncan's test at $5 \%$ significance.

\section{RESULTS AND DISCUSSION}

None of the rabbits showed clinical signs of Amorimia rigida intoxication in agreement with Melo et al. (2) who also had not observed any behavioral alterations in mice after different intake levels of this plant. Conversely, Lago et al. (4) reported that after the administration of $20 \mathrm{~g} / \mathrm{kg}$ of $A$. rigida (Mascagnia rigida) aqueous extract to 10 sheep, signs and symptoms of apathy, exercise intolerance, increased heart rate during rest, loss of appetite and pollakiuria were observed. Moreover, one animal died after five days.

The animals that received $A$. rigida extracts showed diminution $(\mathrm{p}<0.05)$ of aspartate aminotransferase (AST) on the $3^{\text {rd }}$ and $5^{\text {th }}$ days after treatment, respectively, in the insoluble extract (IG) and soluble extract (SG) groups. The AST values for rabbits may vary from 14 to $113 \mathrm{U} / \mathrm{L}$ (13) and therefore all values obtained in the present study were within the threshold for that species (Table 1). There was a decrease ( $\mathrm{p}<$ $0.05)$ of lactate-dehydrogenase (LDH) at T2, T3 and T4 (from $5^{\text {th }}$ to $9^{\text {th }}$ day) in SG animals when compared with T0. The IG rabbits presented a LDH decrease $(\mathrm{p}<0.05)$ only on the $5^{\text {th }}$ day $(\mathrm{T} 2)$. $\mathrm{LDH}$ reference values for rabbits range from 34 to $129 \mathrm{U} / \mathrm{L}$ (14) and therefore the values measured in SG animals on the $5^{\text {th }}$ and $7^{\text {th }}$ days and in IG on the $5^{\text {th }}$ day were below normality.

Guinea pigs intoxicated with A. publiflora (Mascagnia publiflora), another Amorimia specie, presented higher AST values (119.6 U/L) when compared with healthy specimens $(29.69 \mathrm{U} / \mathrm{L})$ (15). However, Melo et al. (2) observed that A. rigida aqueous fractions (tannins, flavonoids, alkaloids and saponins) at $9 \mathrm{~kg} / \mathrm{g}$ dosage did not cause AST alteration in mice, but higher dosages of 18 and $27 \mathrm{~g} / \mathrm{kg}$ administrated for seven consecutive days caused significant increase of that enzyme. The same authors also evaluated

Table 1. Mean serum values of aspartate aminotransferase (AST - U/L) and lactate dehydrogenase (LDH - $\mathrm{U} / \mathrm{L}$ ) in rabbits submitted to gavage with ultra-pure water (CG), water-soluble A. rigida extract (SG) and water-insoluble $A$. rigida extract (IG) at different times

\begin{tabular}{c|c|c|c|c}
\hline & Time $(T)$ & \multicolumn{3}{|c}{ Groups } \\
\hline Variables* & (days) & Control & Soluble & Insoluble \\
\hline & Tzero & $62.00 \pm 26.46^{\mathrm{b}}$ & $88.00 \pm 21.63^{\mathrm{a}}$ & $87.67 \pm 16.62^{\mathrm{a}}$ \\
\hline AST & T1 -3 days & $54.00 \pm 34.83^{\mathrm{b}}$ & $77.00 \pm 2.65^{\mathrm{ab}}$ & $44.00 \pm 13.45^{\mathrm{c}}$ \\
\hline$(\mathrm{U} / \mathrm{L})$ & T2 -5 days & $98.00 \pm 60.63^{\mathrm{a}}$ & $53.33 \pm 14.84^{\mathrm{b}}$ & $59.67 \pm 17.79^{\mathrm{abc}}$ \\
\hline & T3 -7 days & $78.00 \pm 57.38^{\mathrm{ab}}$ & $60.67 \pm 9.29^{\mathrm{ab}}$ & $45.67 \pm 10.02^{\mathrm{bc}}$ \\
\hline $\mathrm{CV}(\%): 43.69$ & T4 -9 days & $77.00 \pm 43.86^{\mathrm{ab}}$ & $73.67 \pm 30.35^{\mathrm{ab}}$ & $78.00 \pm 33.45^{\mathrm{ab}}$ \\
\hline & T zero & $57.00 \pm 27.84^{\mathrm{a}}$ & $89.67 \pm 24.83^{\mathrm{a}}$ & $63.67 \pm 21.39^{\mathrm{a}}$ \\
\hline LDH & T1 -3 days & $61.67 \pm 22.81^{\mathrm{a}}$ & $55.00 \pm 1.00^{\mathrm{ab}}$ & $38.70 \pm 13.67^{\mathrm{ab}}$ \\
\hline$(\mathrm{U} / \mathrm{L})$ & T2 -5 days & $57.00 \pm 6.00^{\mathrm{a}}$ & $29.63 \pm 16.00^{\mathrm{b}}$ & $15.63 \pm 2.49^{\mathrm{b}}$ \\
\hline & T3 -7 days & $43.33 \pm 7.57^{\mathrm{a}}$ & $24.67 \pm 2.52^{\mathrm{b}}$ & $52.67 \pm 32.19^{\mathrm{a}}$ \\
\hline CV(\%): 50.12 & T4 -9 days & $67.67 \pm 44.46^{\mathrm{a}}$ & $36.67 \pm 3.21^{\mathrm{b}}$ & $48.33 \pm 13.01^{\mathrm{ab}}$ \\
\hline
\end{tabular}

$\mathrm{CV}$ : coefficient of variation

*Means followed by same letters do not statistically differ among the times (columns), submitted to the analysis of variance, SNK test (ALT) and Duncan test (LDH) $(p<0.05)$ 
Table 2. Mean serum levels of creatine kinase* (CK - U/L), MB creatine kinase fraction* (CK-MB - U/L) and relative percent of $C K-M B^{*}(C K-M B / C K-\%)$ in rabbits submitted to gavage with ultra-pure water $(C G)$, watersoluble $A$. rigida extract $(\mathrm{SG})$ and water-insoluble $A$. rigida extract $(\mathrm{IG})$ at different times

\begin{tabular}{|c|c|c|c|c|}
\hline \multirow[b]{2}{*}{ Variable } & \multirow{2}{*}{$\begin{array}{c}\text { Time (T) } \\
\text { (days) }\end{array}$} & \multicolumn{3}{|c|}{ Groups } \\
\hline & & Control & Soluble & Insoluble \\
\hline \multirow{5}{*}{$\begin{array}{c}\text { CK } \\
(\mathrm{U} / \mathrm{L}) \\
\text { CV(\%): } 57.42\end{array}$} & T zero & $1112.07 \pm 496.21$ & $1006.73 \pm 198.40$ & $577.80 \pm 190.73$ \\
\hline & T1 - 3 days & $928.03 \pm 378.36$ & $778.10 \pm 250.56$ & $669.40 \pm 270.00$ \\
\hline & T2 - 5 days & $1776.80 \pm 577.36$ & $1195.73 \pm 432.18$ & $1021.57 \pm 649.33$ \\
\hline & T3 - 7 days & $1927.03 \pm 702.35$ & $1559.73 \pm 1111.17$ & $1268.93 \pm 1085.59$ \\
\hline & T4 - 9 days & $1905.87 \pm 847.49$ & $1165.43 \pm 668.12$ & $616.27 \pm 205.03$ \\
\hline \multirow{5}{*}{$\begin{array}{c}\text { CK-MB } \\
(\mathrm{U} / \mathrm{L}) \\
\text { CV(\%): } 64.77\end{array}$} & T zero & $363.73 \pm 214.02$ & $413.67 \pm 178.01$ & $230.43 \pm 177.92$ \\
\hline & T1 - 3 days & $505.40 \pm 346.66$ & $276.30 \pm 46.55$ & $135.47 \pm 55.25$ \\
\hline & T2 - 5 days & $361.03 \pm 136.12$ & $320.00 \pm 165.85$ & $213.17 \pm 58.56$ \\
\hline & T3 - 7 days & $317.87 \pm 88.62$ & $224.50 \pm 142.39$ & $287.10 \pm 212.00$ \\
\hline & T4 - 9 days & $486.27 \pm 142.70$ & $577.70 \pm 578.02$ & $300.30 \pm 116.33$ \\
\hline \multirow{5}{*}{$\begin{array}{c}\text { CK-MB/ } \\
\text { CK (\%) } \\
\text { CV(\%): 55,68 }\end{array}$} & Tzero & $35.89 \pm 27.49$ & $43.68 \pm 26.17$ & $43.33 \pm 29.88$ \\
\hline & T1 - 3 days & $51.19 \pm 15.02$ & $38.77 \pm 15.38$ & $25.66 \pm 21.92$ \\
\hline & T2 - 5 days & $20.39 \pm 5.59$ & $25.40 \pm 6.25$ & $24.35 \pm 9.47$ \\
\hline & T3 - 7 days & $17.20 \pm 4.74$ & $15.06 \pm 4.33$ & $27.44 \pm 14.46$ \\
\hline & T4 - 9 days & $29.90 \pm 15.18$ & $45.01 \pm 22.57$ & $48.13 \pm 2.95$ \\
\hline
\end{tabular}

CV: coefficient of variation

LDH and did not find significant alterations. AST is present in many tissues, including skeletal muscle and heart, and therefore is used as a marker of muscle lesion. However, as a mitochondrial and cytosolic enzyme, a more severe lesion is necessary to cause its release into circulating blood. Similarly, LDH is present in many tissues, including skeletal and striated muscles, mainly in rapid contraction muscles. Its low specificity leads to the evaluation of more specific cardiac markers such as creatine kinase (CK), MB creatine kinase fraction (CK-MB) and troponine, a subunit of muscle structure protein (14).

There were no differences $(\mathrm{P}>0.05)$ in $\mathrm{CK}$, $\mathrm{CK}-\mathrm{MB}$ and $\mathrm{CK}-\mathrm{MB} /$ total $\mathrm{CK}$ ratio after $A$. rigida administration (Table 2). CK-MB/total $\mathrm{CK}$ ratio provides reliable information regarding myocardium injury, since an increase in CK-MB values followed by $\mathrm{CK}$ augmentation may be caused by physical exertion, for example. However, when an increase of CK-MB is not followed by an elevation of total $\mathrm{CK}$, the percentage of this enzyme will be higher, thus confirming a specific lesion of cardiac muscle. Our results differ from those reported by Melo et al. (2), who found an increase of 70 to $84 \%$ in CK-MB after the administration of saponin and alkaloid fractions of $A$. rigida to mice, respectively.

Cardiac troponin I (cTnI) measurements using immunochromatographic test were also unable to detect myocardial lesion. Normal cTnI concentration in healthy rabbits ranges from 0.012 to $0.014 \mathrm{ng} / \mathrm{dL}$ (16). As the reagent concentrations in the immunochromatographic test exceeded $0.5 \mathrm{ng} / \mathrm{mL}$, it is possible to infer the occurrence of myocardial injury with low-level cTnI release. However, the use of this marker to detect experimental cardiac lesions in rabbits revealed values of cTnI much higher than that threshold (17), with plasma concentrations of up to $2 \mathrm{ng} / \mathrm{mL}$ (18). Therefore, all data obtained here demonstrated that there was no damage of cardiac muscle fibers after the administration of aqueous extracts of $A$. rigida. 
The mean heart rate (HR) of all nine animals at T0 was $210(+/-15) \mathrm{bpm}$ after midazolam administration. HR measured in New Zealand rabbits by telemetry (19) without medication presented a mean value of $218(+/-4) \mathrm{bpm}$, which was similar to the value obtained with the sedative protocol proposed in the present study, indicating a close proximity to the resting HR physiological values.

A significant increase $(\mathrm{p}<0.05)$ in the HR values was observed only in SG, from the $3^{\text {rd }}$ to the $7^{\text {th }}$ days, as displayed in Table 3. All HR means were within the expected range for the leporine species (7).

Similarly to what was observed in SG rabbits, sheep experimentally envenomed with $A$. rigida leaves in an aqueous suspension $(20 \mathrm{~g} / \mathrm{kg})$ for three or seven days presented an increase of $\mathrm{HR}$ at rest and mainly during physical effort associated with a decrease of cardiac function (4). At least among humans and dogs (20), cardiac diseases are directly related to altered $\mathrm{HR}$, which increases in intensity to compensate the insufficiency. In animals that presented sudden death associated with $A$. rigida intoxication, tachycardia was one of the signs cited immediately before the onset of death (2).

Cardiac pattern was sinusoidal in almost all animals and times, except in two IG specimens that presented sinusoidal arrhythmia, one at T1 ( $3^{\text {rd }}$ day) and the other at T2 ( $5^{\text {th }}$ day). Such arrhythmia does not have clinical relevance. ECG records did not present any alterations that could represent clinical importance in $A$. rigida intoxication showing normal $\mathrm{P}-\mathrm{QRS}-\mathrm{T}$ complexes.

The PR interval showed a statistically significant difference $(\mathrm{p}<0.05)$ in groups and times of treatment (Table 4), when compared to the control group (CG). As to the groups, SG showed a significant $P R$ decrease at all times when compared to CG. Data from IG were similar to CG only at T2 ( $5^{\text {th }}$ day). With regard to time, PR decreased significantly in SG from the $3^{\text {rd }}$ to the $7^{\text {th }}$ days. This finding may indicate an elevation in the conductibility of the cardiac electric impulse (positive dromotropism), which was not reported in either CG or IG.

The PR interval in rabbits ranges from 60 to $90 \mathrm{~ms}$ (21). Hence, in the SG on the $3^{\text {rd }}$ and $5^{\text {th }}$ days, PR interval mean values were below the minimum threshold.

T-wave values differed little between the groups SG and IG $(\mathrm{P}<0.05)$ at T1 (Table 5$)$. About $52.78 \%$ of ECG had $\mathrm{T}$ wave higher than $25 \%$ of the $\mathrm{R}$ wave, including $\mathrm{T} 0$. The $\mathrm{T}$ amplitude varied from 0.12 to 0.44 , averaging $0.11 \mathrm{mV}$ at DI (21), from which it could be inferred that there was no clinical significance associated with alteration in T wave amplitude.

In our experiment, only one SG animal showed inversion of the $\mathrm{T}$ wave on the $3^{\text {rd }}$ day (T2). It was also submitted to the Holter exam (previously described). The maximum ST-segment deviation never exceeded $1 \mathrm{~mm}$ ( or $0.1 \mathrm{mV}$ ), as also observed by Levine and Bristol (21). The inversion of $\mathrm{T}$ wave polarity in serial ECG is not considered normal (22). These transitory $\mathrm{T}$-wave alterations may indicate a myocardial disease and might occur in the absence of a clinically detectable heart disease. Other conditions associated with this alteration are myocardial hypoxia, hydroelectrolytic disturbances, metabolic diseases and intoxications (6).

Table 3. Heart rate (HR) (bpm) mean values in rabbits submitted to gavage procedure with ultra-pure water (CG), water-soluble A. rigida extract (SG) and water-insoluble A. rigida extract (IG) at different times

\begin{tabular}{c|c|c|c}
\hline Time (T) & \multicolumn{3}{|c}{ HR (bpm)* } \\
\hline (days) & Control Group & Soluble Group & Insoluble Group \\
\hline T zero & $216.67 \pm 7.57^{\mathrm{a}}$ & $203.33 \pm 27.32^{\mathrm{b}}$ & $246.33 \pm 38.21^{\mathrm{a}}$ \\
\hline T1 -3 days & $236.00 \pm 25.71^{\mathrm{a}}$ & $257.67 \pm 23.76^{\mathrm{a}}$ & $231.33 \pm 28.36^{\mathrm{a}}$ \\
\hline T2 -5 days & $254.33 \pm 22.55^{\mathrm{a}}$ & $249.00 \pm 13.75^{\mathrm{a}}$ & $229.67 \pm 22.68^{\mathrm{a}}$ \\
\hline T3 -7 days & $231.33 \pm 19.01^{\mathrm{a}}$ & $244.67 \pm 16.26^{\mathrm{a}}$ & $231.33 \pm 20.03^{\mathrm{a}}$ \\
\hline
\end{tabular}

Coefficient of variation $=10.42 \%$

*Means followed by same letters do not statistically differ among the times (columns), according to analysis of variance and SNK test $(p<0.05)$ 
Table 4. Mean durations of PR interval (msec) in rabbits submitted to gavage procedure with ultra-pure water (CG), water-soluble A. rigida extract (SG) and water-insoluble A. rigida extract (IG) at different times

\begin{tabular}{c|c|c|c}
\hline Time $(\mathrm{T})$ & \multicolumn{3}{|c}{ PR $(\mathrm{msec})^{*}$} \\
\hline (days) & Control Group & Soluble Group & Insoluble Group \\
\hline Tzero & $79.67 \pm 7.02^{\mathrm{Aa}}$ & $69.00 \pm 6.08^{\mathrm{Ba}}$ & $61.33 \pm 2.52^{\mathrm{Ba}}$ \\
\hline T1 -3 days & $74.67 \pm 5.69^{\mathrm{Aa}}$ & $54.33 \pm 5.03^{\mathrm{Bb}}$ & $62.00 \pm 2.65^{\mathrm{Ba}}$ \\
\hline T2 -5 days & $74.00 \pm 4.58^{\mathrm{Aa}}$ & $55.67 \pm 5.77^{\mathrm{Bb}}$ & $65.33 \pm 4.51^{\mathrm{Aa}}$ \\
\hline T3 -7 days & $74.33 \pm 5.51^{\mathrm{Aa}}$ & $60.67 \pm 5.13^{\mathrm{Bb}}$ & $60.67 \pm 3.51^{\mathrm{Ba}}$ \\
\hline
\end{tabular}

Coefficient of variation (\%) PR $=13.63$

*Means followed by the same upper case letter $\mathrm{n}$ the lines and by the same lower case letter in the columns do not differ according to the analysis of variance and SNK test $(p>0.05)$

Alterations in $\mathrm{T}$ wave amplitude were reported in intoxication by cardiac glycosides of Tylecodon wallichii in guinea pigs (23); however, these results occurred in association with alterations in the QRS complex and QT interval just before death, similar to the description of Saad et al. (15).

QRS durations did not differ $(\mathrm{p}>0.05)$ in groups that received $A$. rigida extracts according to data shown in Table 6. The QRS complex varied between 43 and $59 \mathrm{msec}$ in the present study, within the possible range from 20 to $60 \mathrm{msec}$.

Although each animal was in an identical position when the ECGs were performed, changes were observed in $\mathrm{P}$ wave voltage, QRS complex and $\mathrm{T}$ waves including in the CG group. These alterations were also reported in ECG of 23 healthy rabbits, without chemical or physical contention, performed every $48 \mathrm{~h}$, for two weeks, at the same time and under the same conditions (21).
As to the QRS complex, there was individual variation in all animals, mainly in $C G$ and particularly in SG and IG animals before the administration of $A$. rigida extracts. The same results were also demonstrated in sheep intoxicated by this plant (4). These alterations may be caused by the great variability of the vagal mechanisms and extreme mobility of the rabbit heart, which produces inevitable changes in placement (24) and, consequently, of the electrical axis of the heart or intrinsic electrochemical changes of the heart itself (21).

The QT interval is associated with the duration of the action potential of ventricular muscles and increases in cardiopathy $(6,20)$. However, the QT-interval duration is inversely proportional to that of HR and may generate inconsistencies in its analysis during tachycardia, since even if it is prolonged, this effect may be masked by HR increase, thus hampering the drawing of conclusions from its results. Also considering that

Table 5. T wave mean amplitude $(\mathrm{mV})$ in rabbits submitted to gavage with ultra-pure water $(\mathrm{CG})$, watersoluble A. rigida extract (SG) and water-insoluble A. rigida extract (IG) at different times

\begin{tabular}{|c|c|c|c|c|}
\hline & \multirow{2}{*}{$\begin{array}{c}\text { Time }(\mathrm{T}) \\
\text { (days) }\end{array}$} & \multicolumn{3}{|c|}{ Groups } \\
\hline & & Control & Soluble & Insoluble \\
\hline \multirow{3}{*}{$\mathrm{T}(\mathrm{mV})$} & T zero & $0.16 \pm 0.05^{A}$ & $0.11 \pm 0.09^{A}$ & $0.06 \pm 0.04^{A}$ \\
\hline & T1 - 3 days & $0.18 \pm 0.06^{A}$ & $0.06 \pm 0.01^{\mathrm{B}}$ & $0.07 \pm 0.05^{\mathrm{B}}$ \\
\hline & T2 - 5 days & $0.13 \pm 0.04^{\mathrm{A}}$ & $0.05 \pm 0.07^{A}$ & $0.05 \pm 0.05^{A}$ \\
\hline CV(\%): 63.91 & T3 - 7 days & $0.13 \pm 0.03^{A}$ & $0.09 \pm 0.03^{A}$ & $0.07 \pm 0.07^{A}$ \\
\hline
\end{tabular}

CV: coefficient of variation

Means followed by the same upper case letter in the lines and by the same lower case letter in the columns do not differ, according to the analysis of variance, logarithmic transformation $+1(R)$ and SNK test $(p>0.05)$ 
Table 6. QRS complex mean duration in rabbits submitted to gavage with ultra-pure water (CG), watersoluble A. rigida extract $(\mathrm{SG})$ and water-insoluble A. rigida extract $(\mathrm{IG})$ at different times

\begin{tabular}{c|c|c|c}
\hline Time $(T)$ & \multicolumn{3}{|c}{ QRS (msec) } \\
\hline (days) & Control Group & Soluble Group & Insoluble Group \\
\hline T zero & $53.33 \pm 4.93^{\mathrm{ab}}$ & $56.33 \pm 3.79^{\mathrm{a}}$ & $48.67 \pm 5.13^{\mathrm{a}}$ \\
\hline T1 -3 days & $52.67 \pm 2.89^{\mathrm{ab}}$ & $54.00 \pm 1.73^{\mathrm{a}}$ & $45.33 \pm 1.53^{\mathrm{a}}$ \\
\hline T2 -5 days & $48.00 \pm 3.00^{\mathrm{b}}$ & $53.33 \pm 1.53^{\mathrm{a}}$ & $47.00 \pm 2.65^{\mathrm{a}}$ \\
\hline T3 -7 days & $56.00 \pm 1.73^{\mathrm{a}}$ & $51.00 \pm 5.29^{\mathrm{a}}$ & $48.00 \pm 4.00^{\mathrm{a}}$ \\
\hline
\end{tabular}

Coefficient of variation (\%) QRS $=8.93$

Means followed by the same lower case letter in the columns do not differ according to the analysis of variance and SNK test ( $p$ > 0.05)

HR differs in rabbits, it is important to exclude the effect of HR on the QT interval.

The QT reference values for adult New Zealand rabbits, corrected by the Carlsson formula, range from 142 to $157 \mathrm{msec}(25)$. As the QT (U) extrapolation method was used in the present study, but not by Wang et al. (25), there is a trend toward an increase of the interval. When comparing the conventional and the extrapolation methods, several authors (26) also observed the increase of this interval in QT (U) extrapolation.

In comparison to $\mathrm{GC}$, the results indicate that $A$. rigida did not cause cardiac alteration sufficient to increase QTc (Table 7). However, it should be emphasized that a low degree of the intoxication may not have been sufficient to cause the occurrence of increase QTc. Thus, it may be supposed that $A$. rigida did not cause abnormalities in the ventricular action potential and if they occurred they were very slight and could not be demonstrated, probably due to HR increase (4).
All Holter exams, either at T0 or after intoxication ( $9^{\text {th }}$ day), did not show rhythmic disturbances or alterations of conduction that may characterize arrhythmia in these rabbits.

The maximum speed of the aortic flow was lower during the times $(\mathrm{P}<0.05)$ on the $9^{\text {th }}$ day in IG animals (Table 8). A decrease was also observed in the SG group, even though it was not significant. There was no difference of the maximum speed in mitral flow in relation to times or groups $(p>0.05)$, although the mean was greater in IG. The high HR did not allow the individualization of the $\mathrm{E}$ or A mitral waves.

There was no difference $(\mathrm{p}<0.05)$ among the groups and the times regarding $\% \Delta \mathrm{D}$ and ejection fraction (EF) of the left ventricle (Table 9). However, the $\mathrm{EF}$ and the $\% \Delta \mathrm{D}$ showed a decrease of 4 and 7\% between T0 and T9, respectively, in CG animals, while in the treated animals (SG and IG), the respective decreases of $\mathrm{EF}$ and $\% \Delta \mathrm{D}$ were $15.4 \%$ and $23.1 \%$ in $\mathrm{SG}$ and 14 and $20.5 \%$ in IG. The reduction in the ejection fraction and shortening indicates that

Table 7. Mean values of QTc interval (msec) in rabbits submitted to gavage with ultra-pure water (CG), water-soluble $A$. rigida extract (SG) and water-insoluble $A$. rigida extract (IG) at different times

\begin{tabular}{c|c|c|c|c}
\hline & Time $(\mathrm{T})$ & \multicolumn{3}{|c}{ Groups } \\
\hline \multirow{2}{*}{$\begin{array}{c}\text { QTC } \\
\text { (days) }\end{array}$} & Control & Soluble & Insoluble \\
\hline \multirow{2}{*}{ (msec) } & T zero & $171.30 \pm 13.98$ & $166.78 \pm 4.23$ & $163.83 \pm 10.21$ \\
\cline { 2 - 5 } & T1 -3 days & $172.92 \pm 5.58$ & $160.49 \pm 4.77$ & $163.20 \pm 4.98$ \\
\cline { 2 - 5 } & T2 -5 days & $168.30 \pm 15.47$ & $165.93 \pm 7.23$ & $166.42 \pm 6.92$ \\
\cline { 2 - 5 } & T3 -7 days & $165.88 \pm 10.34$ & $166.78 \pm 11.07$ & $165.16 \pm 10.43$ \\
\hline
\end{tabular}

CV: coefficient of variation 
Table 8. Mean maximum flow velocities in aortic valve (VmaxVA - $\mathrm{cm} / \mathrm{s})$ and mitral valve* $(\mathrm{VmaxVM}-\mathrm{cm} / \mathrm{s})$ in rabbits submitted to gavage procedure with ultra-pure water (CG), water-soluble A. rigida extract (SG) and water-insoluble A. rigida extract (IG) at different times

\begin{tabular}{c|c|c|c|c}
\hline & Time $(\mathrm{T})$ & \multicolumn{3}{|c}{ Groups } \\
\hline & (days) & Control & Soluble & Insoluble \\
\hline \multirow{2}{*}{$\begin{array}{c}\text { VmaxVA } \\
(\mathrm{cm} / \mathrm{s}) \\
\text { CV(\%): } 17.39\end{array}$} & T zero & $91.99 \pm 4.97 \mathrm{a}$ & $99.70 \pm 4.11 \mathrm{a}$ & $90.42 \pm 5.28 \mathrm{a}$ \\
\cline { 2 - 5 } & T1 -9 days & $89.50 \pm 2.68 \mathrm{a}$ & $87.88 \pm 4.30 \mathrm{a}$ & $74.46 \pm 14.29 \mathrm{~b}$ \\
\hline $\begin{array}{c}\text { VmaxVM } \\
(\mathrm{cm} / \mathrm{s})\end{array}$ & T zero & $60.75 \pm 8.59$ & $67.45 \pm 5.54$ & $77.75 \pm 13.68$ \\
\cline { 2 - 5 } CV(\%): 10.94 & T1-9 days & $68.12 \pm 6.24$ & $66.51 \pm 15.44$ & $85.19 \pm 11.65$ \\
\hline
\end{tabular}

CV: coefficient of variation

the ventricular systolic function was affected $(12,27)$.

The literature shows a great variation in the reference values for $\mathrm{EF}$ and the other echocardiographic variables. Stypmann et al. (11) used the formula of Fontes-Souza et al. (28), the cubic formula to obtain EF (which is another factor), besides another anesthetic protocol, the conjunction of which prevents the comparison of the values obtained. In another experiment by our research group (5), EF and $\% \Delta \mathrm{D}$ were respectively $75.05 \pm 5.76 \%$ and $40.68 \pm 5.08 \%$ in rabbits sedated with midazolam ( $1 \mathrm{mg} / \mathrm{kg} \mathrm{IM})$. According to this reference and the $C G$ values, there was a decrease of $\mathrm{EF}$ and $\% \Delta \mathrm{D}$ after treatment in SG and IG animals.

A decrease in $\mathrm{EF}$ and $\% \Delta \mathrm{D}$ has already been observed in animals intoxicated by $A$. rigida (Mascagnia rigida) (4). These authors found $\% \Delta \mathrm{D}$ values of $32.4 \%$ and $29.5 \%$ in sheep intoxicated for three and seven days, respectively. The control group values did not change. In our experiment, one SG rabbit presented a 39\% reduction in $\% \Delta \mathrm{D}$ (from $43.7 \%$ to $26.5 \%$ ) versus $34 \%$ in one IG rabbit (from $43.2 \%$ to $28.6 \%$ ).

The final diastolic and systolic volumes of the left ventricle differed significantly $(p<0.05)$; however, the systolic volume was increased in SG and IG animals, whereas CG showed a decrease (Table 10).

The left atrium:aorta ratio (LA/AO) showed a difference $(\mathrm{P}<0.05)$ among the times in IG animals (Table 11), indicating enlargement of LA. The GI rabbits presented the lowest value of this ratio at $\mathrm{T} 0$, revealing a difference after the treatment.

LA length is greatly influenced by the same factors that determine the ventricular distention (pre-load, post-load, contractility, distensibility, contraction and HR) and thus constitutes a stable

Table 9. Mean of the systolic shortening percent* $(\% \Delta D-\%)$ and ejection fraction * $(E F-\%)$ of the left ventricle of rabbits submitted to gavage with ultra-pure water (CG), water-soluble A. rigida extract (SG) and water-insoluble A. rigida extract (IG) at different times

\begin{tabular}{c|c|c|c|c}
\hline \multirow{2}{*}{} & \multirow{2}{*}{$\begin{array}{c}\text { Time (T) } \\
\text { (days) }\end{array}$} & \multicolumn{3}{|c}{ Groups } \\
\cline { 3 - 5 } & & Control & Soluble & Insoluble \\
\hline \multirow{2}{*}{$\begin{array}{c}\mathrm{EF}(\%) \\
\mathrm{CV}(\%): 9.75\end{array}$} & T zero & $70.39 \pm 3.95$ & $73.99 \pm 7.37$ & $77.37 \pm 0.93$ \\
\cline { 2 - 5 }$\% \Delta \mathrm{D}(\%)$ & $\mathrm{T} 1-9$ days & $73.78 \pm 2.41$ & $62.57 \pm 8.07$ & $66.57 \pm 6.40$ \\
\hline \multirow{2}{*}{$\%(\%): 14.46$} & T zero & $36.66 \pm 2.96$ & $40.09 \pm 6.23$ & $42.13 \pm 1.36$ \\
\cline { 2 - 5 } & T1 -9 days & $39.22 \pm 2.11$ & $30.83 \pm 5.48$ & $33.47 \pm 4.80$ \\
\hline
\end{tabular}

CV: coefficient of variation 
Table 10. Mean of the final diastolic volume* (LVFDV - $\mathrm{mL}$ ) and final systolic volume* (LVFSV - $\mathrm{mL}$ ) of left ventricle in rabbits submitted to gavage with ultra-pure water (CG), water-soluble A. rigida extract (SG) and water-insoluble $A$. rigida extract (IG) at different times

\begin{tabular}{c|c|c|c|c}
\hline & Time (T) & \multicolumn{3}{|c}{ Groups } \\
\hline & (days) & Control & Soluble & Insoluble \\
\hline \multirow{2}{*}{$\begin{array}{c}\text { LVFDV } \\
(\mathrm{mL})\end{array}$} & T zero & $5.07 \pm 0.96$ & $5.62 \pm 1.21$ & $4.06 \pm 1.98$ \\
\cline { 2 - 5 } CV (\%): 32.94 & T1 - 9 days & $4.02 \pm 0.50$ & $4.54 \pm 2.44$ & $3.39 \pm 0.96$ \\
\hline $\begin{array}{c}\text { LVFSV } \\
(\mathrm{mL})\end{array}$ & T zero & $1.48 \pm 0.31$ & $1.42 \pm 0.37$ & $0.91 \pm 0.42$ \\
\cline { 2 - 5 } CV (\%): 42.24 & T1 - 9 days & $1.05 \pm 0.14$ & $1.77 \pm 1.11$ & $1.11 \pm 0.26$ \\
\hline
\end{tabular}

*There was no statistical difference according to the analysis of variance $(p>0.05)$

parameter that reflects the duration and severity of the diastolic function $(29,30)$. It is also a good predictor of adverse events in several clinic situations, such as diastolic dysfunction $(31,32)$, independently of the presence of cardiovascular disease, left ventricle systolic dysfunction and ventricular hypertrophy (32). Alteration of LA/ AO ratio provoked by LA enlargement in IG rabbits indicates cardiac diastolic damage of ventricular complacency or relaxing, which may alter the EF (33). Due to the resistance against ventricular distention, the augmented LA contracts more (Frank-Starling law), provoking increase of the atrial flow velocity as previously observed. However, the fact that the entire volume does not fit in the left ventricle causes atrial distention in order to receive the venous return (pre-load overload).

Despite the possibility that $A$. rigida administration may provoke cardiac damage, the results of the echocardiography indicate that the plant affects cardiac function. The post-intoxication decreases of ejection and shortening fractions and aortic flow velocity observed in both SG and IG rabbits reflect a systolic dysfunction of the left ventricle.

The diminished contractility of the left ventricle causes decrease in the ejection volume accounting for the increase in its final systolic volume, thus reducing the cardiac debt (27). In IG animals, it was not followed by an increase of the diastolic volume due to diastolic dysfunction, which may have altered the ventricular distention. In SG animals, the measuring of the final diastolic and systolic volumes after the treatment were impaired by the high standard deviation, although a high elevation in the final systolic volume was recorded. This finding revealed a slight increase compared to the CG group and corroborates the decrease in $\% \Delta \mathrm{D}$.

\section{CONCLUSIONS}

The administration of $30 \mathrm{~g} / \mathrm{kg}$ of Amorimia rigida aqueous extract did not cause any alteration in heart muscle biochemical profile or in the electrocardiographic exams (conventional

Table 11. Left atrium:aorta ratio (LA/AO) in rabbits submitted to gavage with ultra-pure water (CG), watersoluble A. rigida extract $(\mathrm{SG})$ and water-insoluble A. rigida extract $(\mathrm{IG})$ at different times

\begin{tabular}{c|c|c|c|c|}
\hline & Time (T) & \multicolumn{3}{|c|}{ Groups } \\
\hline & (days) & Control & Soluble & Insoluble \\
\hline \multirow{2}{*}{ LE/AO } & T zero & $1.44 \pm 0.11^{\mathrm{a}}$ & $1.79 \pm 0.03^{\mathrm{a}}$ & $1.26 \pm 0.19^{\mathrm{b}}$ \\
\cline { 2 - 5 } CV(\%): 13.34 & T1 -9 days & $1.64 \pm 0.22^{\mathrm{a}}$ & $1.63 \pm 0.09^{\mathrm{a}}$ & $1.63 \pm 0.08^{\mathrm{a}}$ \\
\hline
\end{tabular}

Means followed by the same lower case letter in columns do not differ according to the analysis of variance and SNK test ( $p>0.05)$ 
and Holter) of the experimental rabbits.

Either a decrease in the relaxing or an augmentation of the ventricular complacency provokes a diastolic deficit in the rabbits that received water-insoluble $A$. rigida extract; and a systolic deficit in animals of both groups, detected by Doppler echocardiography.

\section{ACKNOWLEDGMENTS}

Authors would like to thank Prof. Dr. Roberto Baracat de Araújo (Federal University of Minas Gerais State, MG, Brazil) and Prof. Dr. Ruthnea A. L. Muzzi (Federal University of Lavras, MG, Brazil) for providing the Holter analysis facilities.

\section{COPYRIGHT}

\section{(C) CEVAP 2012}

\section{SUBMISSION STATUS}

Received: March 30, 2012.

Accepted: May 28, 2012.

Abstract published online: June 4, 2012.

Full paper published online: August 31, 2012.

\section{CONFLICTS OF INTEREST}

The authors declare no conflicts of interest.

\section{FINANCIAL SOURCE}

The authors wish to thank the Fundação de Amparo a Pesquisa do Estado de Minas Gerais (FAPEMIG) and Conselho Nacional de Desenvolvimento Científico e Tecnológico (CNPq) for financial support for this project.

\section{ETHICS COMMITTEE APPROVAL}

The present study was approved by the Ethics Committee on Animal Experimentation of the Federal University of Minas Gerais (UFMG) (CETEA) under the protocol n187/2008, and followed the protocols of the International Society of Toxinology and the Brazilian Society of Science in Laboratory Animals.

\section{CORRESPONDENCE TO}

Marilia Martins Melo, Escola de Veterinária, Universidade Federal de Minas Gerais, Belo Horizonte, MG, 30.123-970, Brasil. Phone: +55 313409 2229. Fax: +55 313409 2230. Email: mariliamm@ufmg.br.

\section{REFERENCES}

1. Davis CC, Anderson WR. A complete generic phylogeny of Malpighiaceae inferred from nucleotide sequence data and morphology. Am J Botany. 2010;97(12):2031-48.

2. Melo MM, Verçosa Júnior D, Pinto MCL, Silveira JB, Ferraz V, Ecco R, et al. Intoxicação experimental com extratos de Mascagnia rigida (Malpighiaceae) em camundongos. Arq Bras Med Vet Zootec. 2008;60(3):631-40.

3. da Silva P, Lira RA, Barbosa, RR, Batista JS, SotoBlanco B. Intoxicação natural pelas folhas de Mascagnia rigida (Malpighiaceae) em ovinos. Arq Inst Biol. 2008;75(2):229-33.

4. Lago EP, Melo MM, Araújo RB, Nascimento EF, Silva EF, Melo MB. Perfis eletrocardiográfico e ecodopplercardiográfico de ovinos após ingestão da suspensão aquosa de Mascagnia rigida Griseb. (Malpighiaceae). Arq Bras Med Vet Zootec. 2009;61(4):853-62.

5. Silva EF, Borboleta LR, Teles TC, Fonseca VB, Melo MM. EcoDopplercardiografia em coelhos: uso de midazolam e midazolam associado à cetamina. Arq Bras Med Vet Zootec. 2011;63(6):1399-404.

6. Tilley LP. Essentials of canine and feline electrocardiography: interpretation and treatment. $3^{\text {a }}$ ed. Philadelphia: Lea \& Febiger. 1992. p. 470.

7. Pariaut R. Cardiovascular physiology and disease of the rabbit. Vet Clin North Am Exot Anim Pract. 2009;12(1):135-44.

8. Carlsson L, Drews L, Duker G, Schiller-Linnhartd G. Attenuation of proarrhythmias related to delayed repolarization bylow-doselidocaine in the anesthetized rabbit. J Pharmacol Exp Ther. 1993;267(3):1076-80.

9. Oliveira MS, Muzzi RAL, Araujo RB, Nogueira RB, Muzzi LAL, Giannico AT. Holter em animais de campanhia: indicações clínicas e avaliação da variabilidade da frequência cardíaca. Clínica Vet. 2011;16(92):78-86.

10. Cavalcanti GAO, Nogueira RB, Gonçalves FS, Araújo RB, Muzzi RAL, Sampaio GR. Influência da utilização de colar elizabetano ou colar cervical em cães submetidos à eletrocardiografia contínua (Holter). Rev Uni Rural - Série Ciências da Vida. 2007;27(supl):4613.

11. Stypmann J, Engelen MA, Breithardt A, Milberg $\mathrm{P}$, Rothenburger M, Breithardt OA, et al. Doppler echocardiography and Tissue Doppler Imaging in the healthy rabbit: differences of cardiac function during awake and anaesthetised examination. Int J Cardiol. 2007;115(2):164-70.

12. Silva EF, Melo MB, Muzzi RAL, Araújo RB, Tôrres RCS. Índices ecoDopplercardiográficos de função ventricular esquerda em cães das raças Boxer e Schnauzer Miniatura. Arq Bras Med Vet Zootec. 2008;60(1):71-5.

13. Mader DR. Basic approach to veterinary care. In: Hillyer EV, Quesenberry KE. (Eds). Ferrets, rabbits, and rodents - Clinical medicine and surgery. Philadelphia: W.B. Saunders Company. 1997. p. 160-8. 
14. Kaneko JJ, Harvey JW, Bruss ML. Clinical Biochemistry of Domestic Animals. 5a ed. San Diego: Academic Press. 2008. p. 916.

15. Saad AD, Andrade SO, Aguiar AA. The toxic effects of Mascagnia publiflora (Juss.) Griseb. An Acad Bras Cienc. 1970;42:235-44.

16. Jasińska M, Owczarek J, Orszulak-Michalak D. The influence of simvastatin at high dose and diltiazem on myocardium in rabbits, the biochemical study. Acta Pol Pharm. 2006;63(5):386-390.

17. Horton JW, Garcia NM, White DJ, Keffer J. Postburn cardiac contractile function and biochemical markers of postburn cardiac injury. J Am Coll Surg. 1995;181(4):289-98.

18. Pinelli A, Trivulzio S, Tomasoni L, Bertolini B, Brenna S, Bonacina E. Cardiac necrosis markers associated with low nitric oxide levels in the plasma of rabbits after treatment with vasopressin: protective effects of nitroglycerin administration. Pharmacol Res. 2002;45(6):427-34.

19. Marano G, Grigioni M, Tiburzi F, Vergari A, Zanghi F. Effects of isoflurane on cardiovascular system and sympathovagal balance in New Zealand white rabbits. J Cardiovasc Pharmacol. 1996;28(4):513-8.

20. Koyama H, Yoshii H, Yabu H, Kumada H, Fukuda K, Mitani S, et al. Evaluation of QT interval prolongation in dogs with heart failure. J Vet Med Sci. 2004;66(9):1107-11.

21. Levine HD, Bristol NH. Spontaneous changes in the normal rabbit electrocardiogram. Am Heart J. 1942;24(2):209-14.

22. Tattersall ML, Dymond M, Hammond T, Valentin JP. Correction of QT values to allow for increases in heart rate in conscious Beagle dogs in toxicology assessment. J Pharmacol Toxicol Methods. 2006;53(1):11-9.

23. Naudé TW, Schultz A. Studies on South African cardiac glycosides II. Observations on the clinical and haemodynamic effects of cotyledoside. Onderstepoort J Vet Res. 1982;49:247-54.
24. Katz LN, Soskin S, Frisch R. Variations in contour of the records found in serial electrocardiogram of the dog. Exp Biol Med. 1934;32(1):208-9.

25. Wang W, Robertson C, Dhalla AK, Belardinelli L. Antitorsadogenic effects of $(\{+/-\})-\mathrm{N}-(2,6$-dimethylphenyl)-(4[2-hydroxy-3-(2-methoxyphenoxy) propyl]-1-piperazine (ranolazine) in anesthetized rabbits. J Pharmacol Exp Ther. 2008;325(3):875-81.

26. Farkas A, Batey AJ, Coker SJ. How to measure electrocardiographic QT interval in the anaesthetized rabbit. J Pharmacol Toxicol Methods. 2004;50:175-85.

27. Kittleson MD, Kienle RD. Small animal cardiovascular medicine. St. Louis: Mosby. 1998. p. 603.

28. Fontes-Sousa AP, Brás-Silva C, Moura C, Areias JC, Leite-Moreira AF. M-mode and Doppler echocardiographic reference values for male New Zealand white rabbits. Am J Vet Res. 2006;67(10):17259.

29. Basnight MA, Gonzalez MS, Kershenovich SC, Applenton CP. Pulmonary venous flow velocity: relation to hemodynamics, mitral flow velocity and left atrial volume, and ejection fraction. J Am Soc Echocardiogr. 1991;4(6):547-58.

30. Boon JA. Evaluation of size, function, and hemodynamics. In: Manual of veterinary echocardiography. Baltimore: Willians \& Wilkins. 1998. p. 151-260.

31. Simek CL, Feldman MD, Haber HL, Wu CC, Jayaweera AR, Kaul S. Relationship between left ventricular wall thickness and left atrial size: comparison with other measures of daystolic function. J Am Soc Echocardiogr. 1995;8(1):37-47.

32. Pritchett AM, Mahoney DW, Jacobsen SJ, Rodeheffer RJ, Karon BL, Redfield MM. Dyastolic dysfunction and left atrial volume. J Am Coll Cardiol. 2005;45(1):8792.

33. Mesquista ET, Socrates J, Rassi S, Villacorta $H$, Mady C. Insuficiência cardíaca com função sistólica preservada. Arq Bras Cardiol. 2004;82(5):494-500. 